\title{
EKSTRAKSI CIRI SPORA PATOGEN CITRA PENYAKIT PADA TANAMAN JAGUNG BERBASIS TEKSTUR DERAJAT KEABUAN MENGGUNAKAN GRAY LEVEL CO-OCCURENCE MATRIX
}

\author{
Frangky Tupamahu'), Mohamad Lihawa' ${ }^{2)}$, Zulzain Ilahude ${ }^{3)}$ \\ ${ }^{1}$ Program Studi D3 Teknik Informatika, Politeknik Gorontalo \\ ${ }^{2,3}$ Program Studi S1 Agroteknologi, Universitas Negeri Gorontalo \\ E-mail: frangkytupamahu@poligon.ac.id ${ }^{1)}$
}

\begin{abstract}
ABSTRAK
Tanaman yang terinfeksi hama dan penyakit berdasarkan hasil pengamatan dilapangan menunjukan perubahan-perubahan yang nampak terlihat terjadi. Akan tetapi agar proses pengenalan lebih tepat oleh ahli pertanian diambil bagian yang terinfeksi penyakit tersebut yang diletakan pada media posulat Koch untuk dilakukan uji materil di laboratorium untuk dilakukan identifikasi secara visual dibawah mikroskop dan kemudian dilakukan pencocokan berdasarkan referensi ciri-ciri jamur dari pustaka yang digunakan oleh tenaga laboran di laboratorium adapun prosedur identifikasi tersebut yang digunakan kurang efektif dikarenakan dalam proses uji laboratorium untuk menentukan jenis spora pathogen pada tanaman jagung dilakukan beberapa tahapan yang membutuhkan waktu yang lebih lama Penelitian ini bertujuan untuk melakukan ektraksi citra suatu spora pathogen penyakit pada tanaman jagung yaitu penyakit hawar,bercak dan karat pada daun tanaman jagung sehingga diperoleh ciri-ciri berdasarkan visual digital. Berdasarkan hasil penelitian menggunakan ekstraksi fitur Grey Level Co-Occurence Matriks (GLCM) diperoleh hasil untuk spora pathogen penyakit pada tanaman jagung untuk hawar, bercak dan karat daun dari tabel 1 ditunjukan bahwa diperoleh nilai maksimal suatu intensitas maksimal yang sama untuk ketiga penyakit. Untuk nilai kromatis maksimal 0.9 pada penyakit hawar fitur entropi, bercak fitur IDM, dan terakhir pada fitur ASM penyakit hawar dan Karat. Sedangkan untuk nilai intensitas minimal terendah 0.1 adalah pada penyakit karat fitur entropi dan IDM.
\end{abstract}

Kata Kunci: Pengenalan Pola, Patogen, GLCM, Jarak Euclidean

\begin{abstract}
Plants infected with pests and diseases based on field observations showed the changes that appear to look the case. However, in order for the process of the introduction of more appropriate by the expert of agriculture taken part that is infected with the disease which is placed on the Koch postulates media to do material test laboratory to do visually identification under the microscope and then matching is done based on the reference characteristics of mushrooms from the library that is used by personnel in laboratory procedures as for labor identification used the less effective because in the process test laboratory for determine the type of pathogen spores on maize plants carried out several stages which require a longer time this research aims to do imagery extraction of a pathogen disease spores on plant corn blight disease, namely spotting and the rust on the leaves of the plant corn so acquired traits based on visual digital. Based on the results of research using feature extraction of Grey Level Co-Occurrence matrix (GLCM) obtained results for pathogen disease spores on maize plants to blight, leaf spot and rust from table 1 indicated that obtained the maximum value of the same maximum intensity for all three diseases. For the value of the maximum chromatic 0.9 feature blight disease on entropy feature patches, IDM, and lastly on the ASM and blight disease rust. As for the lowest minimum intensity value of 0.1 is in rust diseases feature entropy and IDM.
\end{abstract}

\section{Kata kunci: Pattern Recognition, Pathogens, GLCM, Euclidean Distance}

\section{PENDAHULUAN}

Tanaman Jagung di provinsi Gorontalo dalam satu tahun, petani menanam 2 sampai 3 kali, tergantung kebutuhan dan musim. Produksi tanaman jagung mengalami fluktuasi, hal ini dapat disebabkan oleh berbagai macam, diantaranya yang sangat penting adalah adanya serangan hama dan penyakit. Sekarang ini dengan kondisi iklim yang tidak menentu, memicu terjadinya ledakan hama dan penyakit dan ini akan berdampak pada penurunan produksi jagung. Tanaman yang terinfeksi hama dan penyakit berdasarkan hasil pengamatan dilapangan menunjukan perubahan-perubahan yang nampak terlihat terjadi. Akan tetapi agar proses pengenalan lebih tepat oleh ahli pertanian diambil bagian yang terinfeksi penyakit tersebut yang diletakan pada media posulat Koch (Nuryati \& Sari, 2009) untuk dilakukan uji materil di laboratorium untuk dilakukan identifikasi secara visual dibawah mikroskop dan kemudian dilakukan pencocokan berdasarkan referensi ciri-ciri jamur dari pustaka yang digunakan oleh tenaga laboran di laboratorium (Suada \& Suniti, 
2014). Adapun prosedur identifikasi tersebut yang digunakan kurang efektif dikarenakan dalam proses uji laboratorium untuk menentukan jenis spora pathogen pada tanaman jagung dilakukan beberapa tahapan yang membutuhkan waktu yang lebih (Stewart et al., 2014).

Guna mereduksi dan juga diperoleh efisiensi waktu pada proses uji laboratorium, pemanfaatan teknologi komputasi memberikan peran penting yang ideal agar dieroleh hasil yang maksimal. Pemanfaatkan teknologi komputasi untuk proses identifikasi penyakit pada tanaman telah dilakukan oleh (Bashish, Braik, \& Bani-ahmad, 2010) yaitu membuat sebuah kerangka untuk Deteksi dan klasifikasi tanaman daun dan batang penyakit Dheeb menggunakan metode K-Means diperoleh hasil deteksi 93\%. Selanjutnya penelitian yang dilakukan oleh (Pengyun, 2009) yang pada penelitiannya dilakukan perhitungan jumlah spora pada penyakit tanaman berbasis analisa morfologi top hat serta transformasi citra warna RGB kebentuk derajat keabuan. Pada penelitian ini bertujuan untuk melakukan ektraksi ciri suatu spora pathogen penyakit pada tanaman jagung yaitu penyakit hawar, bercak dan karat pada daun tanaman jagung.

\section{METODE PENELITIAN}

\subsection{Landasan Teori}

Tanaman dikatakan sakit bila ada perubahan seluruh atau sebagian organ-organ tanaman yang menyebabkan terganggunya fisiologis tanaman.

\subsubsection{Penyakit bercak daun (Curvulariasp)}

Penyakit bercak daun pada tanaman jagung dapat disebabkan oleh jamur Curvulariasp., jamur ini sangat cepat penyebarannya dan biasanya, dibantu oleh hembusan angin atau percikan air hujan, dengan gejala yang ditimbulkan adalah ditandai oleh munculnya bintik-bintik kecil kuning kecoklatan yang berukuran 1-2 mm.

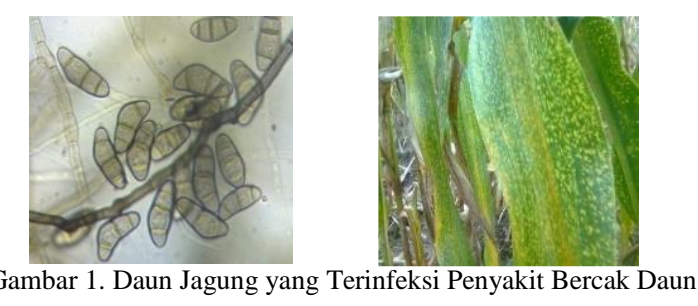

\subsubsection{Penyakit Hawar Daun (Helminthosporium sp)}

Hawar Pada tanaman jagung gambar 2 dapat disebabkan oleh jamur yang pada musim hujan dengan curah hujan yang tinggi sepanjang musim tanam, dapat menyebabkan kerusakan berat. Gejala serangan penyakit hawar daun Helminthosporium $s p$., pada tanaman jagung, mula-mula terjadi bercakbercak kecil, jorong, hijau tua atau hijau kelabu kebasah-basahan, selanjutnya bercak menjadi berwarna coklat kehijauan, lama kelamaan bercak membesar dan mempunyai bentuk yang khas, yaitu berbentuk kumparan bercak yang mepunyai lebar 1$2 \mathrm{~cm}$ dan panjang $5-10 \mathrm{~cm}$; tetapi dapat mencapai lebar $5 \mathrm{~cm}$ dengan panjang $15 \mathrm{~cm}$.
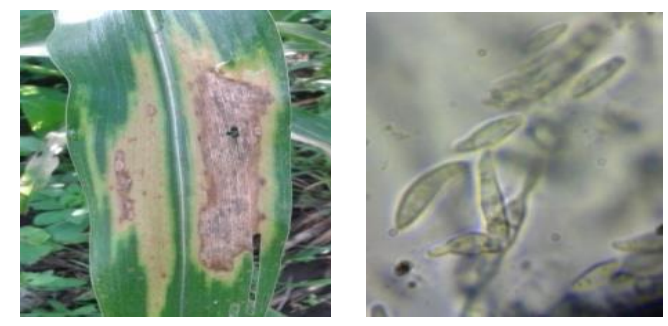

Gambar 1. Daun Jagung yang Terinfeksi Penyakit Hawar

\subsubsection{Karat Daun (Pucinia Sorghis Chwin.)}

Penyakit karat biasanya menyerang tanaman jagung pada stadia generatif, yaitu pada daun tanaman jagung, dan biasanya tidak begitu berpengaruh terhadap hasil tanaman jagung.Gejala yang tampak pada tanaman adalah pada permukaan daun atas dan bawah terdapat bercak-bercak kecil bulat sampai oval, berwarna coklat sampai merah, orange karena cendawan ini membentuk Urediosorus panjang atau bulat panjang pada daun. Epidermis pecah sebagian dan masa spora di bebaskan menyebabkan Urediosorus berwarna coklat atau coklat tua.
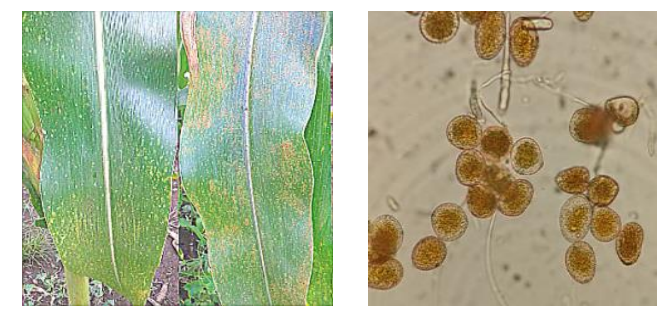

Gambar 3. Daun Jagung yang Terinfeksi Penyakit Karat

\subsubsection{Citra Digital}

Citra digital yang secara prinsipnya merupakan enterpretasi dari nilai-nilai suatu intensitas berasal dari gelombang analog elektromagnetis yang dipancarkan oleh objek yang merupakan ekternal yang langsung diterima oleh sensor charge coupled device (CCD) pada kamera digital. Gelombang elektromagnetis yang diterima oleh sensor ini memiliki panjang gelombang yang bervariasi berdasarkan kekuatan cahaya yang memantul ke objek yang diamati dengan kata lain, proses ini disebut juga dengan konversi nilai dari sistem analog ke dalam bentuk digital seperti ditunjukan pada gambar 4. Panjang gelombang hasil tangkapan sensor tersebut menurut proyeksi yang diterima oleh mata mampu menginterpretasikan suatu warna untuk dikenali oleh otak sebagai warna Merah (Red), Hijua (Green), Biru (Blue). 

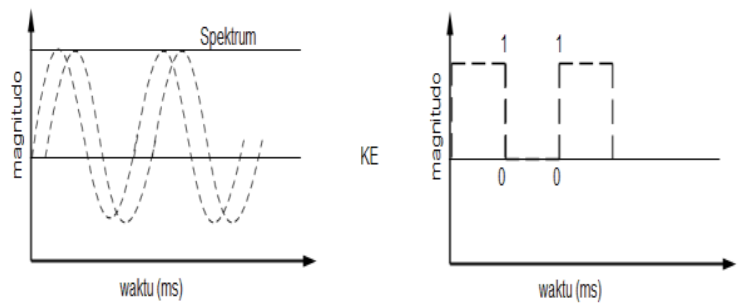

Gambar 4. Konversi Signal Analog ke Signal Digital

Warna-warna tersebut memiliki nilai-nilai dalam jangkaun $0-255$ yang disebut sebagai jangkauan nilai piksel. Hubungan antara panjang gelombang yang dikonversikan dalam bentuk digital, dalam prespektif visualiasi mata manusia jangkauan nilai-nilai tersebut diterjemahkan oleh otak manusia sebagai keseragaman warna dasar seperti ditunjukan pada tabel 1 sebagai berikut.

Tabel 1. Definisi Gambar berdasarkan Panjang Gelombang

\begin{tabular}{|c|c|}
\hline Panjang Gelombang (nm) & Jenis Warna \\
\hline $400-680$ & Merah \\
\hline $400-650$ & Hijaun \\
\hline $370-530$ & Biru \\
\hline
\end{tabular}

Informasi warna yang diperoleh hasil dari foto suatu objek menggunakan kamera digital menghasilkan gambar dengan format grafis dalam bentuk JPG atau JPEG yang merupakan standar umum format yang dihasilkan oleh kamera digital memiliki sifat dasar warna Merah, Hijau dan Biru yang terkompresi kedalam sebuah file gambar Digital dengan bentuk umumnya adalah berbentuk segi empat yang memiliki dimensi ukuran yang bervariasi serta nilai intensitas ditiap-tiap warna yang bervariasi pula dalam jangkauan nilai piksel $0-255$ ditunjukan pada gambar 5

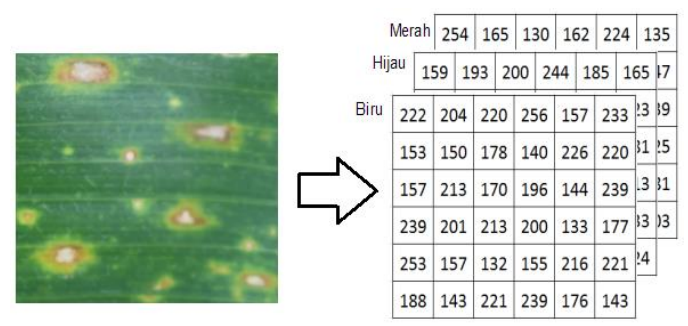

Gambar 5. Konversi Signal Analog ke Signal Digital a. Gambar hasil kamera digital format jpg.

b. nilai piksel warna dasar gambar hasil kamera digita.

Nilai-nilai piksel warna yang terkompresi dalam sebuah gambar digital memiliki variasi nilai indeks membentuk mariks baris dan kolom $f(x, y)$ dalam wujud elemen-elemen matiks yang dinyatakan dalam bilangan bulat yang mendefinsikan bahwa indeks-indeks tersebut merupakan parameter ukur dari suatu intensitas citra digital hasil perekaman menggunakan kamera digital. Banyaknya nilai sebaran suatu intensitas dari citra digital disesuaikan dengan dimensi ukuran citra baris $m x$ kolom $n$ piksel yang dihasilkan oleh kamera digital yang telah di lakukan pengaturan secara manual ataupun mengikuti pengaturan standar kamera yang digunakan.

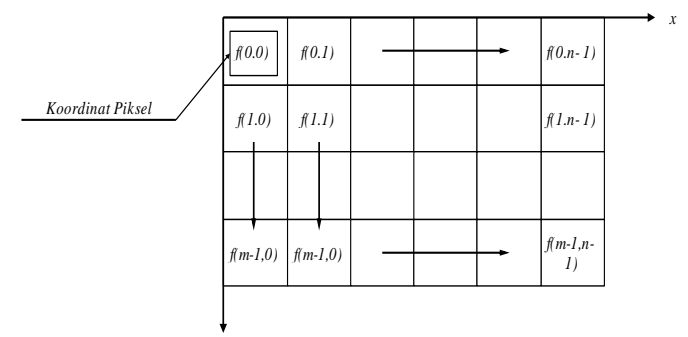

Gambar 6. Hubungan Dimensi dan Titik Koordinat Piksel Citra Digital

Dari gambar 6 tersebut dinyatakan bahwa fungsi citra secara matriks adalah sebagai berikut.

$$
f(x, y)=\left[\begin{array}{lllc}
f(0,0) & f(0,1) & : & f(0, \mathrm{~N}-1) \\
f(1,0) & f(1,1) & : & f(1, \mathrm{~N}-1) \\
: & : & : & : \\
f(\mathrm{M}-1,0) & f(\mathrm{M}-1,0) & : & f(\mathrm{M}-1, \mathrm{~N}-1)
\end{array}\right]
$$

\subsubsection{Transformasi Level Derajat Keabuan}

Transformasi level derajat keabuan (grey level) bertujuan untuk mengubah tingkat abu-abu dari seluruh gambar dalamcara yang seragam atau bermaksud untuk memodifikasi tingkat abu-abu dalam jendela yang ditentukan oleh fungsi pemetaan. Transformasi ini biasanya diharapkan untuk meningkatkan citra Sebaliknya, sehingga detail gambar bisa lebih terlihat. Nilai piksel dengan koordinat $(x, y)$ pada gambar yang ditingkatkan $\hat{f}$ adalah hasil dari melakukan beberapa operasi pada nilai $f(x, \mathrm{y})$ Thresholding adalah kasus paling sederhana untuk menggantikan intensitas profil dengan fungsi langkah, melewati pada nilai ambang yang dipilih. Dalam hal ini, piksel apa pun dengan tingkat abu-abu di bawah ambang batas di gambar input yang diterima 0 dalam gambar output, dan di atas atau sama dengan nilai ambang yang diterima 255 (Shih, n.d.). Operasi sederhana lain, citra negatif, membalikkan urutan pixel intensitas dari hitam putih, sehingga mengurangi intensitas output sebagai intensitas input meningkat. Itu adalah terbalik gambar di mana gambar yang biasanya hitam dengan latar belakang putih terbalik menjadi putih pada latar belakang hitam.

Dengan mengabaikan $r$ tingkat abu-abu input dan output tingkat derajat keabuan berada di kisaran $[0, L-1]$. Hubungan antara input dan output suatu tingkat derajat keabuan dihasilkan oleh $s=[L-1-r]$. gambar 7 menunjukkan gambar spora penyakit dan citra spora penyakit negatif. Operasi negati gambar ini setara dengan fotografi negatif. Hal ini sangat 
berguna untuk menunjukkan rincian kecil daerah putih atau abu-abu ketika mereka muncul dalam latar belakang gelap besar.
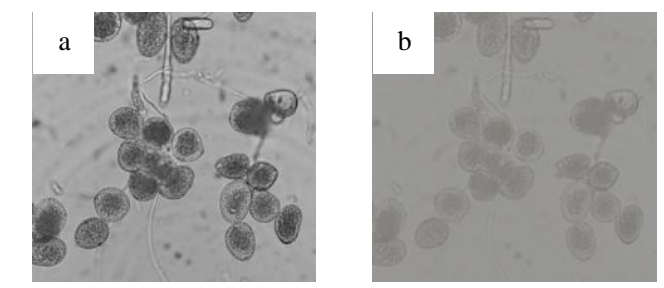

Gambar 7 Citra Spora Patogen dan citra bentuk negative a. Citra Spora Patoge, b Citra Negatif

\subsubsection{Gray Level Coocurence Matrix}

Haralick dkk pertama kali memperkenalkan penggunaan probabilitas kejadian menggunakan GLCM untuk mengekstraksi berbagai tekstur dari suatu citra keabuan. Yang didefinisikan sebagai sebuah histogram dua dimensi tingkat abu-abu untuk sepasang piksel, yang dipisahkan oleh jarak/spatial tetap. GLCM dari sebuah obejk citra dihitung menggunakan perpindahan vektor $d$, yang didefinisikan sebagai arah terdekat dengan memperhatingkan jarak $d$ dan orentasi sudut $\theta$.

Oleh karena itu suatu pengukuran level derajat dari suatu citra aras keabuan menggunakan GLCM. Perhitungan citra uji berdasarkan jarak saptial $d$ dengan interval sudut $0^{\circ}, 45^{\circ}, 90^{\circ}, 135^{\circ}$ dengan jarak yang umum digunakan adalah 1 piksel memperoleh sebuah matrik kokurensi yang dirubah kedalam bentuk matriks yang simetris. Transpose hasil matriks kookurensi dijumlah dengan hasil matriks kookurensi agar mendapatkan sebuah matriks baru yang simentris sebagai mana diperlihatkan pada gambar 8 .

$$
\begin{array}{r}
{\left[\begin{array}{llll}
2 & 2 & 1 & 0 \\
0 & 2 & 0 & 0 \\
0 & 0 & 3 & 1 \\
0 & 0 & 0 & 1
\end{array}\right]+} \\
A \\
A^{T}
\end{array}
$$

Gambar 8.matriks simetris transpose dari matriks kookurensi

Untuk menghilangkan ketergantungan pada ukuran citra (Processing, Toolbox, Transform, Ii, \& Processing, n.d.) GLCM simentris perlu dilakukan normalisasi agar mempunyai rentan nilai 0 dan 1 . Untuk normalisasi GLCM simentris dihitung dengan menggunakan persamaan sebagia berikut.

$$
N_{g}(i, j)=\frac{g(i, j)}{\Sigma_{i} \Sigma_{j} g(i, j)}
$$

Untuk $N_{g}(i, j)$ adalah hasil dari pada normalisasi matriks kejadian dari citra aras keabuan.

\subsubsection{Jarak Euclidean}

Untuk mengetahui jumlah keseragaman dari suatu nilai vektor fitur citra $x$ dilakukan pengukuran terhadap jarak berdasarkan jarak minimum menggunakan formulasi sebagai berikut.

$$
\text { jarak }\|x, y\|=\sqrt{\left(x_{i}-y_{i}\right)^{2}}
$$

$$
\begin{aligned}
& \text { Untuk: } \\
& x_{i}=\text { nilaivektorinput } 1 \\
& y_{i}=\text { nilai vekteroinput } 2
\end{aligned}
$$

\subsection{Skema Penelitian}

Pada penelitian ini proses untuk mendapatkan suatu detail citra dalam hal ini nilai suatu derajat intensitas dari pada citra spora penyakit pada tanaman jagung dilakukan berdasarkan alur proses yang secara sistem digambar pada blok alur diagram pada Gambar 9 sebagai berikut ini.

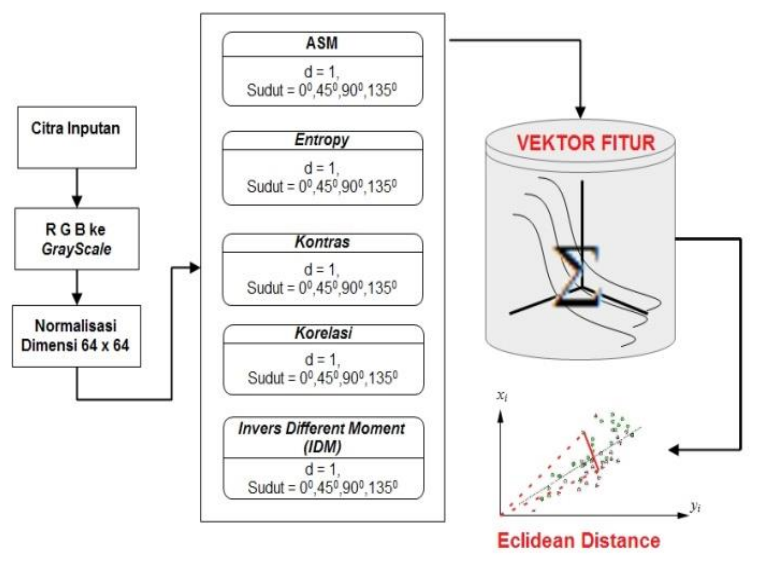

Gambar 9. Blok Diagram Penelitian

\subsubsection{Citra Inputan}

Citra inputan merupakan citra yang digunakan pada penelitian ini untuk diperoleh detail informasi tentang jenis spora pathogen penyakit pada dauan tanaman jagung secara detail. Citra spora patogen yang yang digunakan pada penelitian, merupakan hasil pengumpulan data penyakit yang tersebar dikawasan pertanian Jagung yang dominan ada di Provinsi Gorontalo yang sebagai mana telah diketahui sebelumnya berdasarkan hasil informasi yang diperoleh dari Dinas Pertanian dan Balai pertanian dan perlindungan Tanaman Pertanian (BPTP) Provinsi Gorontalo. hasil dari pada pengambilan penyakit-penyakit tersebut selanjutnya dilakkan isloasi yang dilakukan di Laboratorium BPTP untuk diproleh spora pathogen penyakit. Pada tahapan isolasi ini, proses identifikasi dan reisolasi/pemurnian masa dari pada pada pathogen dilakukan selama 1 minggu dan selanjutnya hasil tersebut di tangkap menggunakan mikroskop jenis binokuler merek olimpus dengan pembesaran yang 
digunakan konstan 40x/0.65mm untuk diperoleh gambar dalam bentuk jpg yang hasilnya tersebut ditunjukan pada gambar 10 berikut ini.

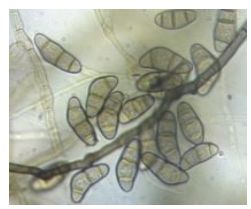

a. Bercak Daun

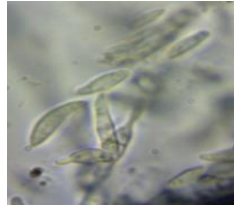

b. Hawar Daun

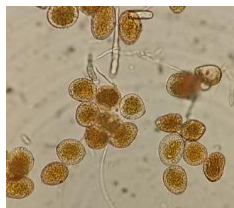

c. Karat Daun
Gambar 10. Citra Masukan

Inputan citra dalam bentuk hasil dari pada mikroskop yang berektensi jpg, merupakan citra murni dengan intensitas yang berjumlah 90 citra dengan dimensi 640 x 460 yang terdistribusi untuk spora patogen penyakit hawar berjumlah 30 buah, bercak 30 dan karat 30 buah.

\subsubsection{RGB to GrayScale}

Pada penelitian ini citra hasil perekaman menggunakan kamera pada mikroskop binokulaer dalam bentuk citra yang tersusun atas tiga elemen warna yaitu merah $(R)$, Hijau $(G)$, Biru $(B)$ dikonversi menjadi bentuk citra lever derajat keabuan. Hal ini dilakukan dengan tujuan untuk memaksimalkan kinerja proses eketraksi fitur berdasarkan tekstur pada citra digital menggunakan persamaan (3) sebagai berikut.

$$
\text { keabuan }(x, y)=\frac{(\mathrm{x}, \mathrm{y}, \text { Red })+(\mathrm{x}, \mathrm{y}, \text { Green })+(\mathrm{x}, \mathrm{y}, \text { Blue })}{I_{\text {warna }}}
$$

Ada pun hasil dari pada konversi citra berwarna kedalam bentuk citra keabuan dilihat pada gambar 3 sebagai berikut.
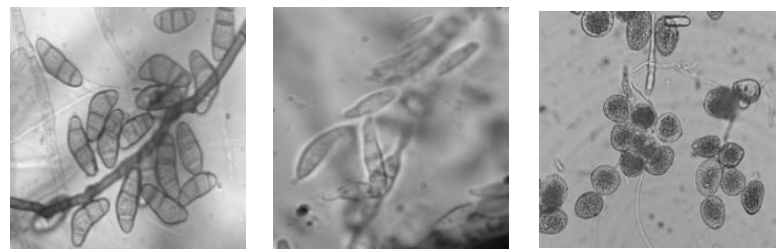

Gambar 11. Konversi RGB ke Derajat Keabuan

\subsubsection{Normalisasi Dimensi}

Citra hasil yang diperoleh menggunakan kamera mikroskop jenis binokuler memiliki ukuran dimensi 640 x 460 piksel yang secara komputasi dimensi tersebut kurang efektif untuk dilakukan analisis secara image processing oleh karena itu citra hasil tersebut dilakukan proses normalisasi agar waktu lebih efektif dalam melakukan analisis.

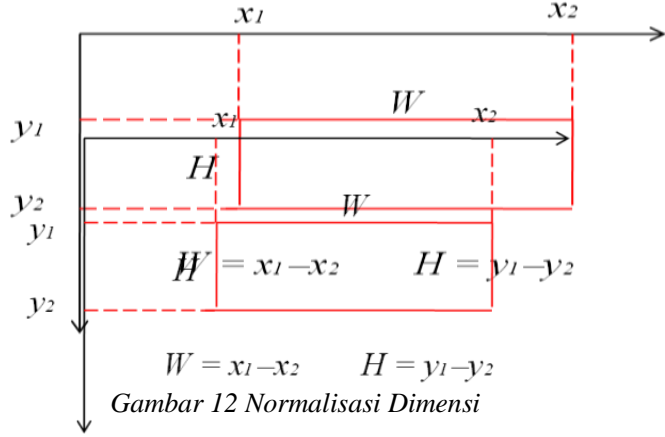

\subsubsection{Matriks Level Derajat Keabuan}

Angular second moment (ASM) juga dikenal sebagai keseragaman atau energi, mengukur homogenitas citra. ASM bernilai tinggi ketika pixels sangat mirip. Dengan menggunakan persamaan (4) nilai ASM dari sebuah citra dapat diketahui.

$A S M=\sum_{i=0}^{G-1} \sum_{j=0}^{G-1}\{\mathrm{P}(\mathrm{i}, \mathrm{j})\}^{2}$

Inverse different moment (IDM)juga biasa disebut homogenitas lokal, mengukur homogenitas citra yang berderajat keabuan sejenis. IDM mengembalikan ukuran kedekatan distribusi elemen GLCM ke GLCM diagonal.

$I D M=\sum_{i=0}^{G-1} \sum_{j=0}^{G-1} \frac{1}{1+(\mathrm{i}-\mathrm{j})^{2}} \mathrm{P}(\mathrm{i}, \mathrm{j})$

Entropi menyatakan ukuran ketidak teraturan aras keabuan di dalam citra. Nilainya tinggi jika elemen-elemen GLCM mempunyai nilai yang relatif sama. Nilai rendah jika elemen-elemen GLCM dekat dengan nilai 0 atau 1 . Persaman memperoleh nilai entropy (6)

$E N T=-\sum_{i=0}^{G-1} \sum_{j=0}^{G-1} \mathrm{P}(\mathrm{i}, \mathrm{j}) \times \log (\mathrm{P}(\mathrm{i}, \mathrm{j}))$

Kontras adalah ukuran dariintensitas atau gray-level variasi antara pixel referensi dan tetangganya.

Corr $=\sum_{n=0}^{G-1} n^{2}\left\{\sum_{i=1} \sum_{j=1} P(i, j)\right\},|i-j|=n$

Korelasi yang merupakan ukuran ketergantungan linear antar nilai aras keabuan dalam citra. Dihitung menggunakan persamaan (8)

Corr $=\sum_{i=0}^{G-1} \sum_{j=0}^{G-1} \frac{\{\mathrm{i} x \mathrm{j}\} x \mathrm{P}(\mathrm{i}, \mathrm{j})-\left\{\mu_{x} x \mu_{y}\right\}}{\sigma_{x} . \sigma_{y}}$

\section{HASIL DAN PEMBAHASAN}

Berdasarkan hasil ektraksi fitur dari 3 jenis spora penyakit tanaman jagung yaitu penyakit hawar, bercak dan karat berdasarkan citra derajat keabuan 
menggunakan fitur Grey Level Co-occurence Matrix (GLCM).
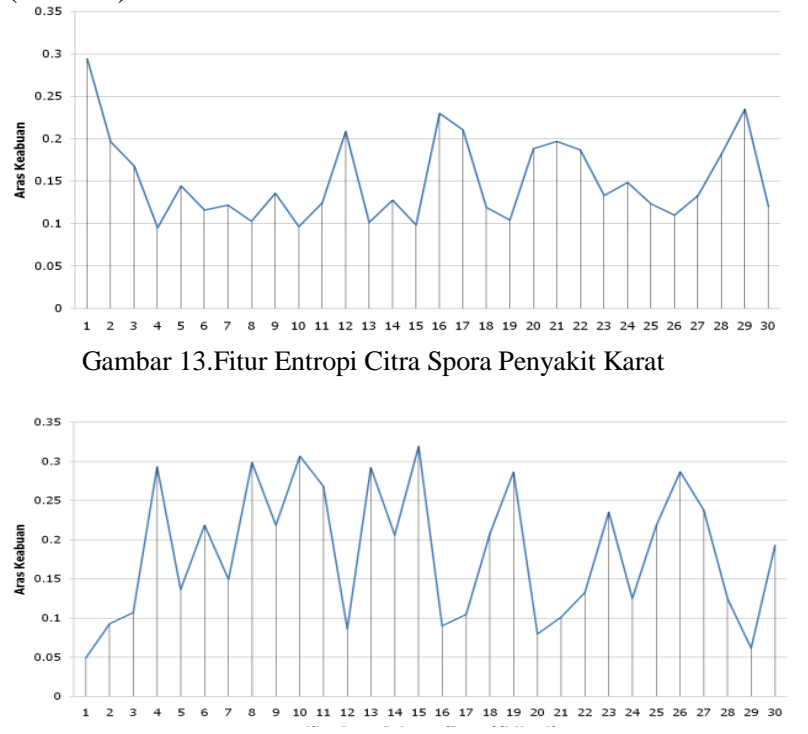

Gambar 14 Fitur IDM Citra Spora Penyakit Karat

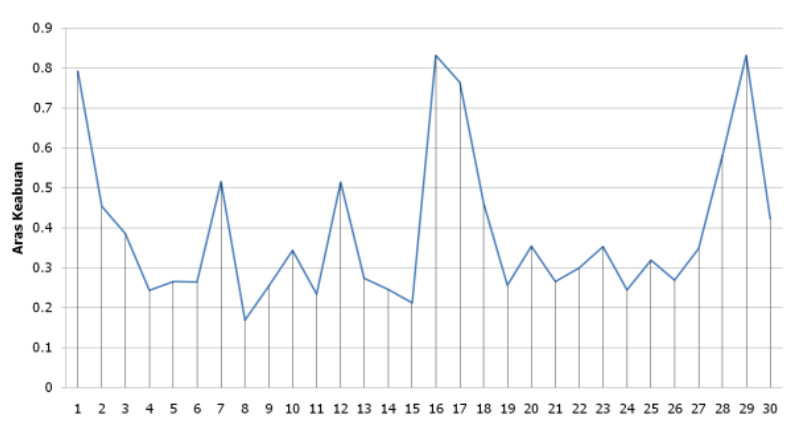

Gambar 15 Fitur Kontras Citra Spora Penyakit Karat
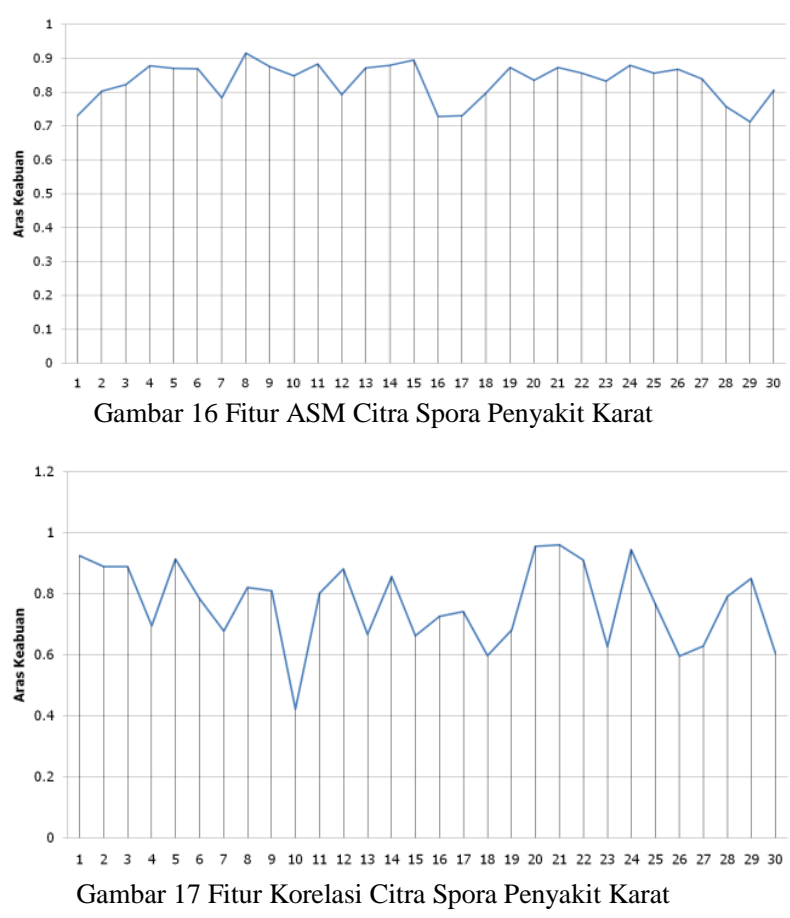

Dari hasil ektraksi menggunakan salah satu fitur pada GLCM yaitu entropi untuk penyakit karat pada gambar 13 diperoleh hasil ektraksi yang terdistribusi pada nilai intensitas maksimal 0.34 dan minimal 0.15 . Untuk fitur IDM pada gambar 14, nilai intensitas yang dihasilkan berada pada bentangan nilai maksimal 0.32 dan minimal 0.06. dan selanjutnya fitur kontras penyakit karat terlihat nilai intensitas yang terdistribusi seperti ditunjukan pada gambar 16 diperoleh hasil yang maksimal adalah 0.83 dan minimal 0.16. kemudian untuk fitur ASM penyakit karat terlihat distribusi nilai intensitas memiliki nilai maksimal yaitu 0.92 dan minimal 0.71 dan terakhir fitur korelasi dari GLCM citra keabuan pada gambar 15 diperoleh hasil nilai distribusi intensitas yang maksimal 0.96 dan minimal 0.42 .
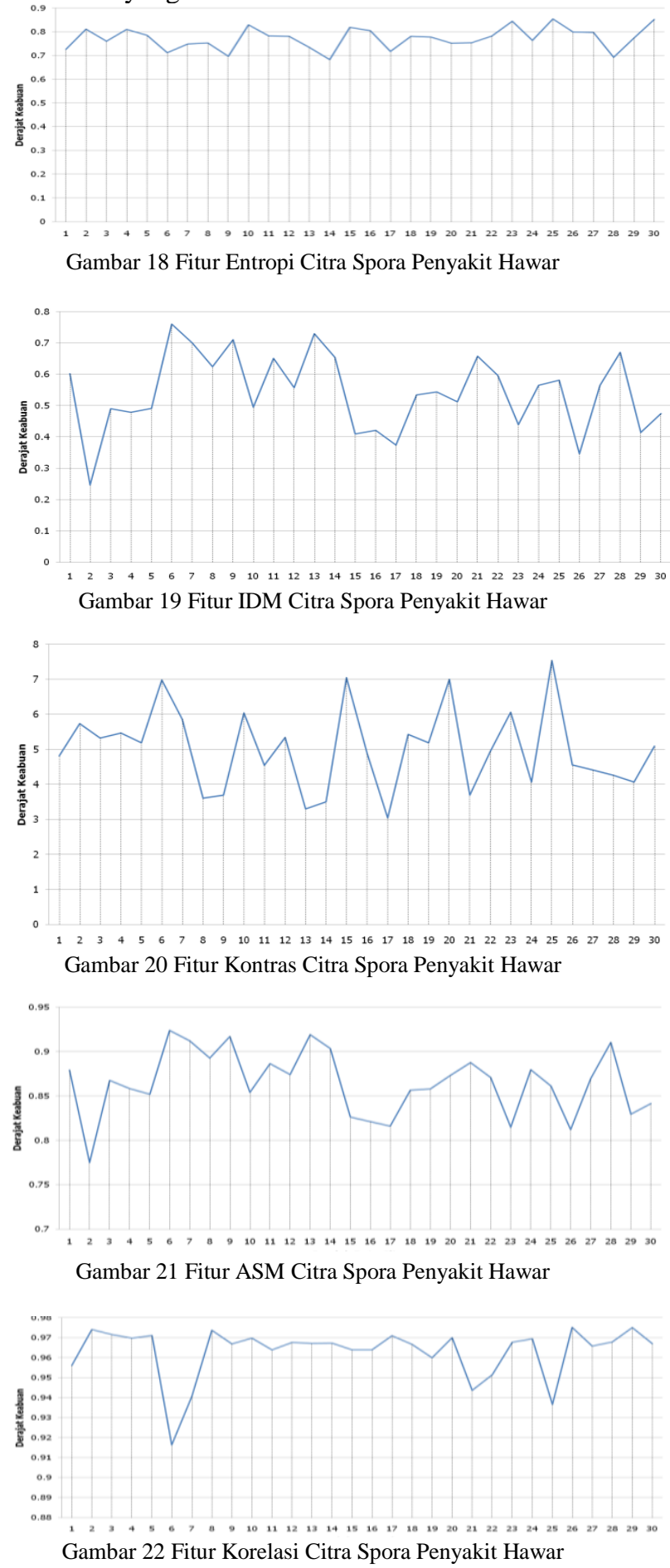
Ektraksi ciri penyakit selanjutnya adalah penyakit hawar diperoleh hasil bahwa dari hasil ektraksi menggunakan salah satu fitur pada GLCM yaitu entropi untuk penyakit hawar pada gambar 10 diperoleh hasil ektraksi yang terdistribusi pada nilai intensitas maksimal 0.85 dan minimal 0.63. Untuk fitur IDM pada gambar 18, nilai intensitas yang dihasilkan berada pada bentangan nilai maksimal 0.76 dan minimal 0.25 . dan selanjutnya fitur kontras penyakit hawar terlihat nilai intensitas yang terdistribusi seperti ditunjukan pada gambar 19 diperoleh hasil yang maksimal adalah 7.54 dan minimal 3.04. kemudian untuk fitur ASM gambar 20 penyakit hawar terlihat distribusi nilai intensitas memiliki nilai maksimal yaitu 0.93 dan minimal 0.77 dan terakhir fitur korelasi dari GLCM citra keabuan pada gambar 22 diperoleh hasil nilai distribusi intensitas yang maksimal 0.97 dan minimal 0.77.
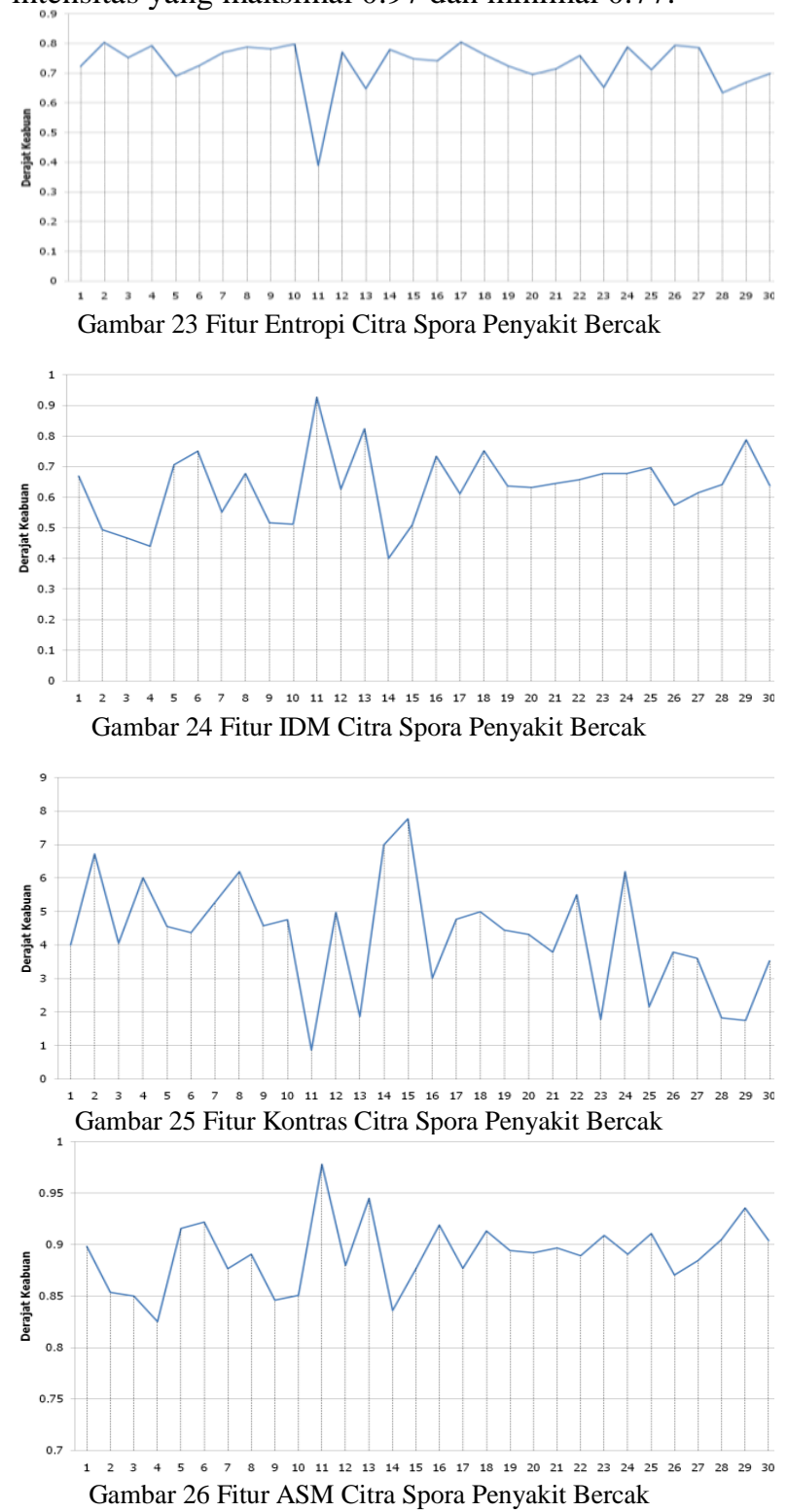

Gambar 26 Fitur ASM Citra Spora Penyakit Bercak

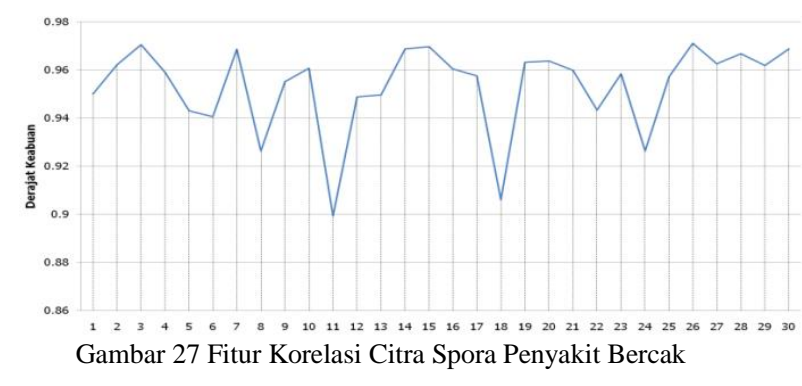

Ektraksi ciri penyakit selanjutnya adalah penyakit bercak diperoleh hasil bahwa dari hasil ektraksi menggunakan salah satu fitur pada GLCM yaitu entropi untuk penyakit bercak pada gambar 23 diperoleh hasil ektraksi yang terdistribusi pada nilai intensitas maksimal 0.80 dan minimal 0.39. Untuk fitur IDM pada gambar 24, nilai intensitas yang dihasilkan berada pada bentangan nilai maksimal 0.93 dan minimal 0.40 . dan selanjutnya fitur kontras penyakit bercak terlihat nilai intensitas yang terdistribusi seperti ditunjukan pada gambar 25 diperoleh hasil yang maksimal adalah 7.77 dan minimal 0.83 kemudian untuk fitur ASM gambar 26 penyakit bercak terlihat distribusi nilai intensitas memiliki nilai maksimal yaitu 0.98 dan minimal 0.83 dan terakhir fitur korelasi dari GLCM citra keabuan pada gambar 27 diperoleh hasil nilai distribusi intensitas yang maksimal 0.97 dan minimal 0.90 . yang secara keseluruhannya secara detail hasil dari pada distribusi intensitasl derajat keabuan menggunakan fitur GLCM ditunjukan pada tabel 1 sebagai berikut.

Tabel 2 Distribusi nilai max dan min Fitur GLCM

\begin{tabular}{|c|c|c|c|c|c|c|c|c|c|c|c|c|c|c|c|}
\hline \multirow[b]{3}{*}{ Jenis } & \multirow{2}{*}{\multicolumn{3}{|c|}{$\begin{array}{l}\text { Entropi } \\
\text { Penyakit }\end{array}$}} & \multirow{2}{*}{\multicolumn{3}{|c|}{$\frac{\text { IDM }}{\text { enyakit }}$}} & \multirow{2}{*}{\multicolumn{3}{|c|}{$\begin{array}{l}\text { Kontras } \\
\text { Penyakit }\end{array}$}} & \multirow{2}{*}{\multicolumn{3}{|c|}{$\frac{\text { ASM }}{\text { Penyakit }}$}} & \multicolumn{3}{|c|}{ Koralasi } \\
\hline & & & & & & & & & & & & & & enyak & \\
\hline & & 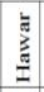 & 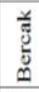 & 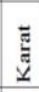 & 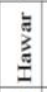 & 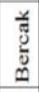 & $\begin{array}{l}\vec{\pi} \\
\underline{n}\end{array}$ & 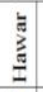 & 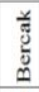 & $\underset{\mathrm{E}}{\tilde{\mathrm{E}}}$ & $\sum_{\underline{g}}$ & \begin{tabular}{l|} 
弟 \\
$\stackrel{0}{0}$ \\
$\stackrel{0}{0}$
\end{tabular} & $\underset{\underline{g}}{\underline{a}}$ & $\underset{\underline{z}}{\underline{z}}$ & 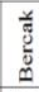 \\
\hline & & & & 0.3 & & 0.9 & 0.8 & 7.5 & 7.8 & 0.9 & 0.9 & 1.0 & 1.0 & 1.0 & 1.0 \\
\hline Nilai Min & 0.1 & 0.7 & 0.4 & 0.1 & 0.2 & 0.4 & 0.2 & 3 & 0.9 & 0.7 & 0.8 & 0.8 & 0.4 & 0.9 & 0.9 \\
\hline
\end{tabular}

\section{KESIMPULAN}

Berdasarkan hasil penelitian menggunakan ekstraksi fitur Grey Level Co-Occurence Matriks (GLCM) diperoleh hasil untuk spora pathogen penyakit pada tanaman jagung untuk hawar, bercak dan karat daun dari tabel 1 ditunjukan bahwa diperoleh nilai maksimal suatu intensitas maksimal yang sama untuk ketiga penyakit. Untuk nilai kromatis maksimal 0.9 pada penyakit hawar fitur entropi, bercak fitur IDM, dan terakhir pada fitur ASM penyakit hawar dan Karat. Sedangkan untuk nilai intensitas minimal terendah 0.1 adalah pada penyakit karat fitur entropi dan IDM.

\section{DAFTAR PUSTAKA}

Bashish, D. Al, Braik, M., \& Bani-ahmad, S. (2010). A Framework for Detection and Classification of Plant Leaf and Stem Diseases, 113-118. 
Nuryati, S., \& Sari, F. B. P. (2009). Identifikasi Dan Uji Postulat Koch Cendawan Penyebab Penyakit Pada Ikan Gurame Identification and Koch Postsulate Test of Fungal Causative Disease in Gouramy Fish, 8(2), 21-27.

Pengyun, X. (2009). Computer assistance image processing spores counting, 203-206. https://doi.org/10.1109/CAR.2009.10

Processing, I., Toolbox, I. P., Transform, F., Ii, P., \& Processing, V. (n.d.). Practical Image and Video Processing Using MATLAB. Retrieved from

https://books.google.co.id/books?id=xzD25Q

Eo8qYC\&lpg=PP1\&dq=PRACTICAL

IMAGE AND VIDEO PROCESSING USING

MATLAB\&pg $=P P 1 \# v=$ onepage $\& q=P R A C T$

ICAL IMAGE AND VIDEO PROCESSING USING MATLAB\& $\mathrm{f}=$ false

Shih, F. Y. (n.d.). IMAGE PROCESSING AND PATTERN Fundamentals and Techniques. Retrieved from https://books.google.co.id/books?id=M_Lr8 NTfAHcC\&lpg=PP1\&dq=IMAGE PROCESSING AND PATTERN RECOGNITION Fundamentals and Techniques\&pg $=\mathrm{PP} 1 \# \mathrm{v}=$ onepage $\& \mathrm{q}=\mathrm{IMAG}$ E PROCESSING AND PATTERN RECOGNITION Fundamentals and Techniques $\& \mathrm{f}=$ false

Stewart, L., Stewartii, P., Stewartii, S., Rahma, H., Zainal, A., Surahman, M., ... Bakteri, I. (2014). POTENSI BAKTERI ENDOFIT DALAM MENEKAN PENYAKIT, 14(2), $121-127$.

Suada, I. K., \& Suniti, N. W. (2014). DAN ANALISIS SECARA MOLEKULER, 14(2), $142-151$. 